\title{
Effect of the addition of papain enzyme on digestive parameters and palatability of extruded diets for dogs
}

\author{
Efeito da adição da enzima papaína em rações extrusadas \\ para cães sobre parâmetros digestivos e palatabilidade
}

\author{
Karine de Melo SANTOS ${ }^{1}$; Fabiano Cesar SÁ ${ }^{3}$; Danilo Ferreira de SOUZA³; Flavio Lopes da SILVA3 \\ Maria Isabel Gonzalez URREGO²; Thiago Henrique Annibale VENDRAMINI'; \\ Márcio Antonio BRUNETTO ${ }^{1}$; Aulus Cavalieri CARCIOFI ${ }^{3}$ \\ ${ }^{1}$ Universidade de São Paulo, Faculdade de Medicina Veterinária e Zootecnia, \\ Departamento de Nutrição e Produção Animal, Pirassununga - SP, Brazil \\ ${ }^{2}$ Universidade de São Paulo, Faculdade de Zootecnia e Engenharia de Alimentos, \\ Departamento de Zootecnia, Pirassununga - SP, Brazil \\ ${ }^{3}$ Universidade Estadual Paulista "Júlio de Mesquita Filho", Faculdade de Ciências Agrárias \\ e Veterinárias, Departamento de Clínica e Cirurgia Veterinária, Jaboticabal - SP, Brazil
}

\begin{abstract}
Common protein sources used in the manufacturing of diets for dogs are derived from by-products, which may have reduced digestibility depending on the source. This study evaluated the effect of the addition of a protease, the papain enzyme, as a supplement to extruded diets on palatability, nutrient digestibility, and fecal production and quality of dogs. A diet was formulated with poultry by-product meal, meat and bone meal, and feather meal as protein sources. This formula was divided into three isonutrient diets: one negative control (NC), without enzymes; treatment one (EZ1) with addition of 855.000 UI of papain per kilogram of diet, and treatment two (EZ2) with addition of 2.280.000 UI of papain per kilogram of diet, both added before extrusion. The experiment followed a randomized block design, with two blocks of nine animals (three animals per treatment in each block), 18 dogs in total, and six replicates per treatment. Data were submitted to analysis of variance and the means of three treatments were compared by polynomial contrasts $(\mathrm{P}<0.05)$. No differences in the coefficients of total tract apparent digestibility of nutrients nor changes in palatability, $\mathrm{pH}$, and fecal production among treatments were found with the addition of different doses of enzyme to the diets $(\mathrm{P}>0.05)$. The fecal score was reduced with increased addition of enzyme $(\mathrm{P}<0.05)$.
\end{abstract}

Keywords: Additive. Canine. Digestibility. Protein.

\section{Resumo}

As fontes comuns de proteína utilizadas na fabricação de rações para cães são oriundas de coprodutos, os quais podem apresentar digestibilidade reduzida de acordo com a fonte. Este estudo avaliou os efeitos da adição da enzima papaína em dietas secas e extrusadas na palatabilidade, digestibilidade dos nutrientes, qualidade e produção fecal de cães adultos. Uma dieta foi formulada contendo farinha de vísceras de frango, farinha de carne e ossos e farinha de penas hidrolisadas como fontes proteicas. Esta foi posteriormente dividida em três dietas isonutrientes: controle negativo (CN) sem adição da enzima; adição de 855.000 UI de papaína por quilograma de ração (EZ1); e adição de 2.280.000 UI de papaína por quiilograma de ração (EZ2), ambas adições feitas antes da extrusão. O experimento seguiu delineamento em blocos casualizados, com dois blocos de nove animais (três animais por tratamento em cada bloco), totalizando 18 cães, e seis repetições por tratamento. Os dados obtidos foram submetidos a análise de variância, com as médias dos três tratamentos comparadas por contrastes polinomiais $(P<0,05)$. Não foram verificadas diferenças nos coeficientes de digestibilidade aparente dos nutrientes ou mesmo alterações na palatabilidade, $\mathrm{pH}$ e produção de fezes entre os tratamentos com diferentes inclusões de enzima $(\mathrm{P}>0,05)$. Apenas o escore fecal reduziu com o aumento da adição da enzima $(\mathrm{P}<0,05)$.

Palavras-chave: Aditivo. Canino. Digestibilidade. Proteína. 
Correspondence to:

Márcio Antonio Brunetto

Universidade de São Paulo, Faculdade de Medicina Veterinária

e Zootecnia, Departamento de Nutrição e Produção Animal

Av. Duque de Caxias Norte, 225

CEP 13635-900, Pirassununga, SP, Brazil

e-mail: mabrunetto@usp.br

Received: 19/01/2017

Approved: 17/11/2017

\section{Introduction}

In order to improve the nutritional value of products, the use of exogenous feed additives has increased. Exogenous enzymes may improve the digestibility of nutrients by reducing anti-nutritional factors that promote increased nutrient availability for digestion (FUENTE; SOTO-SALANOVA, 1997), in addition to promoting a reduction in the synthesis of endogenous enzymes; therefore, the body provides more amino acids for protein synthesis (ZANELLA et al., 1999). According to Wang et al. (2006), supplementation with enzymes has the potential to improve the use of amino acids in the diet and reduce supplementation costs.

Proteolytic enzymes are one of the most important groups of industrial enzymes (KUMAR; TAKAGI, 1999). Among proteases, papain family stands out for being one of the most widely studied (GRZONKA et al., 2001). It is extracted from the latex of papaya (Carica papaya), with the appearance of viscous fluid with about $15 \%$ dry matter. The portion containing the enzyme corresponds to $40 \%$ of the dry matter content and more than $80 \%$ of the total enzyme fraction is composed of the sum of cisteinases and endopeptidases (AZARKAN et al., 2003). After the release of latex from the plant, endopeptidases present in latex veins as inactive proforms are rapidly converted into active enzymes (SILVA et al., 1997; MOUTIM et al., 1999). Although papain represents only about $8.0 \%$ of papaya endopeptidases, this was the most easily purified (MITCHEL et al., 1970).

According to Mezhlumyan et al. (2003), the strong proteolytic action of exogenous proteases could increase the digestibility of protein sources. Another benefit would be the possible release of amino acids, which could provide flavor and taste to food through the neuroreceptors of dogs (NRC, 2006).

Poultry by-product meal, meat and bone meal, and feather meal have already been used in the formulation of diets for dogs, but their inclusion cannot be increased due to the risk of digestibility reduction and decreased quality of animal feces (MURRAY et al., 1997; CAVALARI et al., 2006). Thus, the addition of papain enzyme has the potential to provide greater inclusion of these ingredients, reducing the formulation cost without compromising palatability, nutrient digestibility, and fecal quality.

Given the above, this study aimed at evaluating the effects of the addition of papain enzyme in extruded diets for adult dogs on palatability, digestibility, and fecal output.

\section{Material and Methods}

The project was approved by the Ethics Research Committee on Animal Use (CEUA), College of Agricultural and Veterinary Sciences, São Paulo State University (UNESP), in Jaboticabal (Protocol 019479/11 of 05/09/2011).

\section{Experimental diets}

An isonutrient diet was formulated (Table 1), in which nutritional composition reached recommendations for maintenance of adult dogs according to the Association of American Feed Control Officials (2008). This formulation was divided into three treatments on the basis of papain addition: negative control (NC) without the addition of enzyme; 855.000 UI addition of papain enzyme per kilogram of diet (EZ1); addition of 2.280.000 UI of papain enzyme per kilogram of diet (EZ2). The papain enzyme used was extracted from the latex of papaya fruits (Carica papaya), product commercially known as Papain (Sigma Aldrich, St. Louis, EUA), and added in the pre-conditioning phase of extrusion process for each treatment. The process sequence of the diets was NC, EZ1, and EZ2. The analyzed chemical composition of the diet (asfed basis) was: $8.54 \%$ moisture, $27.13 \%$ crude protein, $11.74 \%$ acid-hydrolyzed fat, $2.68 \%$ crude fiber, $7.72 \%$ mineral matter, and $4.56 \mathrm{kcal} / \mathrm{g}$ gross energy.

\section{Animals and study design}

Eighteen male and female beagle dogs with $7.5 \pm$ 1.5 years old and $12.2 \pm 2.0 \mathrm{~kg}$ of body weight were used. All animals were clinically evaluated prior to the beginning of the study and considered healthy. During the digestibility assay, animals were individually housed in metabolic cages $(0.9 \times 0.9 \times 0.9 \mathrm{~m})$ equipped with a system to separate feces and urine for collection. The amount of food offered was calculated according to the metabolizable energy value of food and energy requirement of the animal, estimated according to the following equation $\mathrm{MER}=130 \times \mathrm{BW}^{0.75}$ (NRC, 2006). The total amount was divided into two equal daily meals and offered at 8:30 AM and 5:30 PM. Water was provided ad libitum. 
The experiment followed a randomized block design with three diets and two blocks of nine animals each, for a total of 18 dogs and six replicates per diet. In each period diet adaptation occurred from days 1 to 5 , and total collection of feces and urine from days 6 to 10 .

Table 1 - Ingredient composition of experimental diets - FCAV/ UNESP, Jaboticabal, SP - 2012

\begin{tabular}{lccc}
\hline \multirow{2}{*}{ Ingredient (g/kg DM) } & \multicolumn{3}{c}{ Diets $^{1}$} \\
\cline { 2 - 4 } Maize & 440.90 & 439.40 & 436.90 \\
Poultry by product-meal & 173.00 & 173.00 & 173.00 \\
Broken rice & 100.00 & 10.00 & 10.00 \\
Meat and bone meal & 80.00 & 80.00 & 80.00 \\
Poultry fat & 66.30 & 66.30 & 66.30 \\
Feather meal & 60.00 & 60.00 & 60.00 \\
Wheat bran & 50.00 & 50.00 & 50.00 \\
Brewer's dried yeast & 10.00 & 10.00 & 10.00 \\
Vitamin-mineral premix ${ }^{2}$ & 5.00 & 5.00 & 5.00 \\
Salt & 5.00 & 5.00 & 5.00 \\
Potassium chloride & 4.10 & 4.10 & 4.10 \\
Calcium carbonate & 2.30 & 2.30 & 2.30 \\
Choline chloride & 2.00 & 2.00 & 2.00 \\
Mold inhibitor & 1.00 & 1.00 & 1.00 \\
Antioxidant & & 0.40 & 0.40 \\
Papain enzyme & - & 0.15 & 0.40 \\
\hline
\end{tabular}

${ }^{1} \mathrm{NC}$, without enzymes; EZ1, addition of 855.000 UI of papain enzyme per kilogram of diet; EZ2, addition of 2.280.000 UI of papain enzyme per kilogram of diet

${ }^{2}$ Addition for kg of product: Iron $100 \mathrm{mg}$; Copper $9.25 \mathrm{mg}$; Manganese 6.25 mg; Zinc $150 \mathrm{mg}$; Iodine $1.87 \mathrm{mg}$; Selenium $0.13 \mathrm{mg}$; vitamin A $18.7500 \mathrm{UI}$; vitamin D $1500 \mathrm{UI}$; vitamin K $0.15 \mathrm{mg}$; Thiamine $5 \mathrm{mg}$; Riboflavin $16 \mathrm{mg}$; Pantotenic acid $35.75 \mathrm{mg}$; Niacin $62.5 \mathrm{mg}$; Piroxidin $7.5 \mathrm{mg}$; Cobalamin 45 mcg; Folic acid $0.75 \mathrm{mg}$

${ }^{3}$ Mold-Zap Aquativa, Alltech Brazil Ltda Agro Araucaria, PR, Brazil): ammonium propionate, propanediol, propionic acid, acetic acid, lactic acid, ascorbic acid, formic acid, potassium sorbate

${ }^{4}$ Banox, (Alltech Brazil Ltda Agro Araucaria, PR, Brazil): BHA, BHT, propyl gallate and calcium carbonate

\section{Palatability evaluation}

The food preference test was conducted at the Mogiana Alimentos SA (Guabi) company, Campinas - SP, with a qualified panel of 45 adult, male and female dogs of all sizes and breeds. The experimental period was 24 hours and food was offered twice daily in alternate sides of the feeder at each meal, and the amount of food offered was twice the maintenance energy requirement (CARCIOFI, 2008). Palatability was assessed by calculating the intake ratio (IR), according to the formula: IR = food intake A / (food intake $\mathrm{A}+$ food intake $\mathrm{B}$ ), in which: $\mathrm{IR}=$ less than 0.49 , preference for food $B ; I R=0.49$ to 0.61 , no preference or the same food palatability; IR = greater than 0.61 , preference for food $\mathrm{A}$. The following palatability challenges were conducted: NC x EZ1, NC x EZ2, and EZ1 x EZ2.

\section{Digestibility}

During the collection period, feces and urine volume were individually collected, weighed and/or measured twice a day and kept frozen $\left(-15^{\circ} \mathrm{C}\right)$ until analysis. Stool produced during the collection period was evaluated for dry matter content, organic and mineral matter, crude protein, crude fiber, fat, and gross energy. During the collection fecal quality was measured according to the following score system: $0=$ liquid stools; $1=$ soft and formless stool; 2 = soft and malformed stool, taking the form of the collection container; 3 = soft, formed, moist feces, marking the floor; $4=$ well-formed and consistent stool that does not mark the floor; $5=$ well-formed, hard and dry stool (CARCIOFI et al., 2008). The fecal pH was the mean measured during the last 3 consecutive days of collection.

Based on laboratory results, the coefficient of total tract apparent digestibility of nutrients (CTTAD) of dry matter (DM), crude protein (CP), acid-hydrolyzed fat (AHF), organic matter (OM), nitrogen free extract (NFE), and gross energy (GE) were calculated according to the equation of Pond et al. (1995).

\section{Laboratory analyses}

At the end of each experimental period, the pool feces samples of each animal were thawed, homogenized and dried in a forced air oven at $55^{\circ} \mathrm{C}$ for 72 hours. Feces and diet samples were analyzed for dry matter (DM), crude protein $(\mathrm{CP})$, crude fiber (CF), mineral matter (MM), and acid-hydrolyzed fat (AHF) according to the Association of the Official Analytical Chemists (2005). Gross energy (GE) was determined by bomb calorimeter (Model 1261; Parr Instrument Company, Moline, IL, USA). Moisture content was calculated by $100-\% D M$. Nitrogen-free extract (NFE) was determined using the following equation NFE $\%=100-$ (\% Moisture + \% CP + \% CF + \% AHF + \% MM). The organic matter was obtained by subtracting the ash content from the dry matter content.

\section{Statistical Analyses}

Data were evaluated using the GLM function of the SAS software (Statistical Analysis System for Windows 9.3, SAS Institute Inc., Cary, USA). The model used considered the block, treatment, and animal effects. Means were compared by polynomial contrasts. Values of $P<0.05$ were considered significant. 


\section{Results}

All diets were adequately consumed by dogs, and no episodes of vomiting, diarrhea or refusal were observed, suggesting tolerance regarding the inclusion of enzymes.

During the palatability test, a comparison between NC and EZ1 treatments obtained RI $=0.78$, which indicated preference for NC. The comparison between NC and EZ2 obtained $\mathrm{RI}=0.55$, or no preference for any food. Finally, the ingestion ratio of EZ1 and EZ2 treatments was 0.77 , indicating preference for EZ1 (Figure 1).
Nutrient intake and the coefficient of apparent digestibility results are shown in table 2. The papain inclusion did not affect the DM, OM, CP, AHF, MM, NFE intake $(P>0.05)$, except the $\mathrm{CF}(P<0.05)$, where a positive linear effect was observed with an inclusion of enzymes. With regards to the coefficient of apparent digestibility, none of the nutrients were influenced by enzyme addition $(P>0.05)$. Regarding the fecal parameters assessed (Table 3 ), only the fecal score differed among diets $(P<0.05)$, and the lowest score was observed on the EZ2 treatment. Fecal $\mathrm{pH}$, fecal dry matter and fecal organic matter did not differ between treatments.

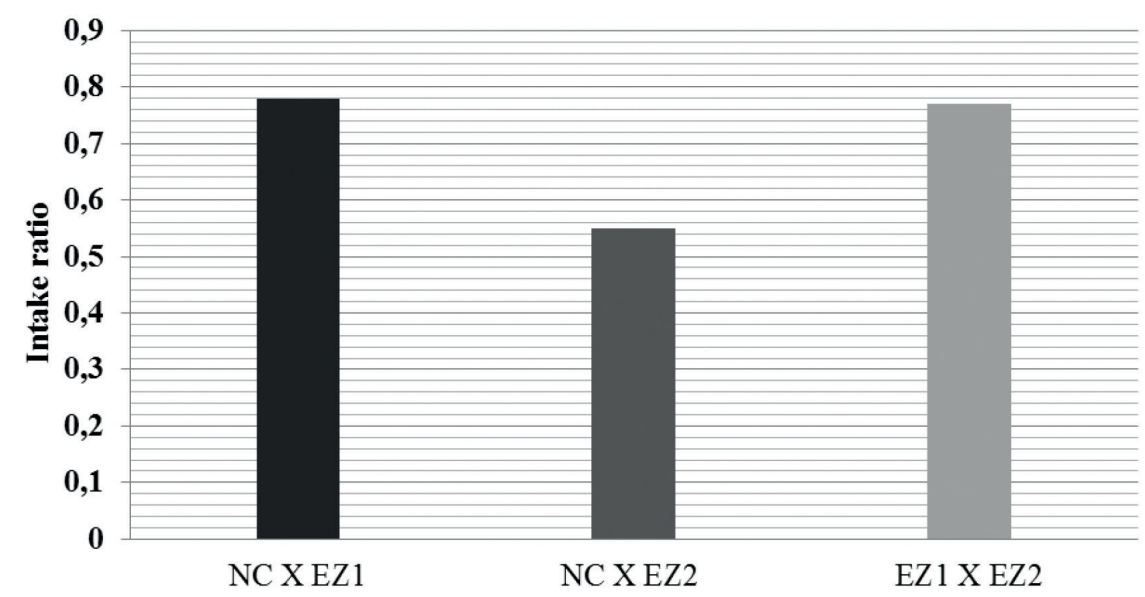

Figure 1 - Comparison of intake rate between NC (negative control, without the addition of enzyme) and EZ1 (855.000 UI addition of papain enzyme per kilogram of diet), NC and EZ2 (2.280.000 UI addition of papain enzyme per kilogram of diet) and the ingestion ratio of EZ1 and EZ2

Table 2 - Nutrient intake and digestibility coefficients of experimental diets - FCAV/UNESP, Jaboticabal, SP - 2012

\begin{tabular}{|c|c|c|c|c|c|c|c|}
\hline \multirow{2}{*}{ Item } & \multicolumn{3}{|c|}{ Diets $^{1}$} & \multirow{2}{*}{ SEM $^{2}$} & \multirow{2}{*}{ P-value } & \multicolumn{2}{|c|}{ Polynomial contrasts } \\
\hline & NC & EZ1 & EZ2 & & & Linear & Quadratic \\
\hline Body weight averaged (kg) & 11.18 & 12.05 & 13.30 & 0.820 & 0.301 & - & - \\
\hline \multicolumn{8}{|l|}{ Food Intake (g/dog/day) } \\
\hline Dry matter & 189.9 & 201.91 & 217.50 & 10.18 & 0.272 & - & - \\
\hline Organic matter & 190.92 & 202.46 & 216.44 & 10.19 & 0.326 & - & - \\
\hline Mineral matter & 17.33 & 18.06 & 20.94 & 0.94 & 0.070 & - & - \\
\hline Crude protein & 61.95 & 65.67 & 69.95 & 3.30 & 0.348 & - & - \\
\hline Ether extract in acid hydrolysis & 26.55 & 28.11 & 30.90 & 1.43 & 0.194 & - & - \\
\hline Crude fiber & 5.39 & 6.66 & 7.50 & 0.32 & $0.003^{* *}$ & $<0.001^{* *}$ & 0.603 \\
\hline Nitrogen free extract & 97.00 & 102.01 & 108.07 & 5.13 & 0.427 & - & - \\
\hline \multicolumn{8}{|c|}{ Apparent digestibility coefficients (\%) } \\
\hline Dry matter & 83.99 & 82.50 & 83.22 & 0.73 & 0.545 & - & - \\
\hline Organic matter & 87.79 & 86.35 & 86.99 & 0.60 & 0.400 & - & - \\
\hline Mineral matter & 42.05 & 39.30 & 44.08 & 2.33 & 0.560 & - & - \\
\hline Crude protein & 84.80 & 83.56 & 83.63 & 0.76 & 0.642 & - & - \\
\hline Ether extract in acid hydrolysis & 91.72 & 90.55 & 91.13 & 0.36 & 0.350 & - & - \\
\hline Crude fiber & 28.39 & 32.86 & 36.14 & 3.43 & 0.216 & - & - \\
\hline Nitrogen free extract & 91.94 & 90.48 & 91.51 & 0.53 & 0.276 & - & - \\
\hline Gross energy & 88.36 & 86.65 & 87.71 & 0.58 & 0.252 & - & - \\
\hline
\end{tabular}

${ }^{1} \mathrm{NC}$, without enzymes; EZ1, addition of 855.000 UI of papain enzyme per kilogram of diet; EZ2, addition of 2.280.000 UI of papain enzyme per kilogram of diet; ${ }^{2} \mathrm{SEM}$, standard error of the mean. ${ }^{* *} P<0.01$ 
Table 3 - Production and fecal characteristics of dogs according to the consumption of experimental diets - FCAV/UNESP, Jaboticabal, SP - 2012

\begin{tabular}{|c|c|c|c|c|c|c|c|}
\hline \multirow{2}{*}{ Item } & \multicolumn{3}{|c|}{ Diets $^{1}$} & \multirow{2}{*}{ SEM $^{2}$} & \multirow{2}{*}{ P-value } & \multicolumn{2}{|c|}{ Polynomial contrasts } \\
\hline & NC & EZ1 & EZ2 & & & Linear & Quadratic \\
\hline Fecal pH & 6.70 & 6.62 & 6.70 & 0.10 & 0.9201 & - & - \\
\hline Fecal score ${ }^{3}$ & 3.92 & 3.8 & 3.02 & 0.12 & $0.0002^{* *}$ & $<0.001^{* *}$ & $0.042^{*}$ \\
\hline Feces dry matter (g/dog/day) & 31.13 & 36.12 & 37.25 & 2.13 & 0.1923 & - & - \\
\hline Fecal dry matter (\%) & 40.37 & 40.05 & 38.98 & 0.89 & 0.0695 & - & - \\
\hline Feces organic matter (g/dog/day) & 77.44 & 90.75 & 96.13 & 6.24 & 0.1092 & - & - \\
\hline
\end{tabular}

${ }^{1} \mathrm{NC}$, without enzymes; EZ1, addition of 855.000 UI of papain enzyme per kilogram of diet; EZ2, addition of 2.280 .000 UI of papain enzyme per kilogram of diet ${ }^{2}$ SEM, standard error of the mean

${ }^{3}$ Fecal score - scores from 0 to $5 .{ }^{*} \mathrm{P}<0.05 ;{ }^{* *} \mathrm{P}<0.01$

\section{Discussion}

No preference for either diet could be observed - the addition of papain did not change the palatability of these diets. Félix et al. (2012) found that the supplementation with carbohydrase enzymes stimulated food intake in dogs, as the first choice when compared to the same diet without enzymes. No other information in literature about this effect in dogs was found, and more studies are needed in order to understand the role of enzymes in stimulating food intake in these animals.

Differences in nutrient intake among treatments were observed only for crude fiber, and the CTTAD of all nutrients did not show a significant difference. The higher fiber consumption has a direct relation with fecal score alteration, which was also observed in this study. Depending on the type, fiber has a different function in the fecal matter formation, maintenance of gastrointestinal tract transit and peristalsis. Further discussion of these results and the actual assertion is also limited due to the methodology of analysis employed, which did not distinguish the type of fiber consumed. Thus for the higher consumption of crude fiber observed, the authors attribute this finding to the methodology used for the determination of fiber content. Crude fiber is a deficient technique that underestimates the amount of fiber present in the samples, by destroying all its soluble and part of the insoluble fractions (CECCHI, 2003).

This technical deficiency is proven in the evaluation of food for dogs and cats by the studying of Oliveira et al. (2012) in which six dry dog foods and six dry cat foods were evaluated for fiber composition and digestibility, comparing a total dietary fiber, neutral and acid detergent fiber and crude fiber. The results demonstrated that crude fiber analysis did not correlate with any other method.

Another recent study (FARCAS et al., 2013) evaluates the differences between maximum crude fiber concentrations and total dietary fiber concentrations (which would be the gold standard method currently) in 20 dry and 20 moist non-therapeutic foods for dogs, and the authors concluded that in lack of information on total dietary fiber concentration (as is the case of our study) no crude fiber concentration appears to be a particularly reliable indicator of fiber concentration and composition of a canine diet.

The main limitation is related to the fact of not separating the cellulose from hemicellulose and solubilizing part of the lignin as well as hemicellulose. This method provides values that may change due to use of too drastic digestion, which leads to loss of some components (CECCHI, 2003), and therefore the values and the differences obtained in our study may not be substantially affirmed.

In broilers, Garcia et al. (2000) found that the digestibility coefficients of DM, CP, and GE of experimental diets were not affected by the addition a multi-enzymatic complex (alpha-galactosidase, pectinase, cellulose, and protease). Likewise, in the study by Ruiz et al. (2008), the enzymatic complex (amylase, pentosanase, cellulase, protease, and alpha-galactosidase) did not promote increase in the nutrient digestibility of diets for pigs. However, these results differ from those found by Barbosa et al. (2008), where the supplementation of the enzymatic complex (amylase, protease, xylanase, and phytase) in diets based on corn and soybeans, with low nutritional content availability to the animal, improved the digestibility of $\mathrm{CP}$, calcium, and phosphorus in the performance of broilers.

Also with dogs (SÁ et al., 2013), the addition of different doses of a blend of enzymes (glucanase, xylanase, cellulase, glucoamylase, amylase, phytase) before and after extrusion in wheat bran based diets for dogs did not result in significant changes in digestibility and fecal quality $(P<0.05)$. In the study of Twomey et al. (2003a) the CTTAD of CP was reduced linearly $(P<0.001)$ with increasing 
levels of soluble non-amylaceous polysaccharide, but increased $(P<0.01)$ with the spray of enzymes (xylanase, glucanase, and amylase). The enzyme solution was sprayed onto the feed at the time of feeding. The dogs that did not receive the enzyme received an equivalent amount of water added to their diets before the meal.

In the extrusion process the mixture of ingredients remains in conditioner from 8 to 180 seconds and can reach temperatures up to $90^{\circ} \mathrm{C}$ and further, achieving $140^{\circ} \mathrm{C}$ during extrusion (LOGATO, 2000). According to Oliveira (2000) and Batistuzzo et al. (2006), above $80^{\circ} \mathrm{C}$ protease can undergo rapid inactivation. Also according to Batistuzzo et al. (2006), the $\mathrm{pH}$ has great influence on the activity of the enzyme papain, since it acts at a $\mathrm{pH}$ of 3.5 to 9.0 with the optimum activity between $\mathrm{pH}$ of 5.0 and 7.0. When the $\mathrm{pH}$ of the solution is greater than 9.0 or less than 3.0 the enzyme is rapidly inactivated. This fact reinforces that the inactivation of the enzyme was not only due to the temperature of the extrusion, but also due to the low $\mathrm{pH}$ of the stomach of dogs, which is physiologically below 3.0 according to Case et al. (2011),

Considering the above and based on the results of this study, it is not possible to affirm if the papain enzyme dosage was insufficient or if the enzyme added in the diets was inactivated during the extrusion process or in the dog stomach.

Few studies have evaluated the effects of food processing on the action of enzymes, a fact that hinders further discussion as none focuses on protease activity (SHIN et al., 2005; DE PILLI et al., 2009; SÁ et al., 2013),

In the study of Twomey et al. (2003b), a total of $1000 \mathrm{~mL}$ of an enzyme solution containing xylanase (225.000 UI), $\alpha$-amylase (18,750 UI), a-glucanase (82,500 UI), hemicellulase $\left(6 \times 10^{7} \mathrm{UI}\right)$, pectinase $\left(4 \times 10^{6} \mathrm{UI}\right)$, and endoglucanase (150,000 UI) were prepared in sufficient quantity for each ton of food manufactured, following a 200 times dilution to aid homogeneity of mixing. The enzyme solution was sprayed onto the feed at the time of feeding, and the addition of the enzyme significantly increased the fecal scores of dogs fed with diets based on corn, sorghum, poultry meal, and maize gluten. In the referred study fecal samples were scored using the Waltham Fecal Scoring System (MOXHAN, 2001). The difference in fecal scores among diets made with rice, corn and sorghum was small and did not cause the fecal mean score to exit the ideal range - similar results were found in this study. It is important to remember that the scale used in this study is inverted to express the same score. In another study the inclusion of different dosages of enzymes blend (proteases, cellulases, pectinases, phytases, betaglucanases, xylanase) did not influence production and fecal quality of dogs fed diets with soybean meal (TORTOLA et al., 2013).

Cowieson et al. (2006) observed that some exogenous enzymes might increase the excretion of endogenous material from the gastrointestinal tract. The excretion of dry matter and endogenous energy increased $(P<0.05)$ with the administration of pectinase, protease, and cellulase, compared to broilers that received the control treatment. The addition of protease increased $(P<0.05)$ the excretion of all amino acids except for histidine, isoleucine, leucine, tyrosine, and valine. This loss may cause an increase in endogenous energy losses, nitrogen, amino acids, and dry matter in the excreta. Nonetheless, this effect may not be applicable to this study because, in theory, the papain enzyme was inactivated in the extruder barrel, in addition to denature and loss of its function in the stomach of dogs.

\section{Conclusion}

The use of papain enzyme under the conditions of this study did not influence the palatability of the diets, nor nutrient digestibility or fecal production. Studies regarding the influence of the extrusion process and different doses of this enzyme may be necessary in order to understand its effect in palatability and digestibility of nutrients in diets for dogs.

\section{Acknowledegments}

Fundação de Amparo à Pesquisa do Estado de São Paulo (FAPESP, Process n. 2011/17502-3) and Mogiana Alimentos S. A. (GUABI) for the financial support to carry out this study. There is no conflict of interest among the authors.

\section{References}

ASSOCIATION OF AMERICAN FEED CONTROL OFFICIALS (AAFCO). Association of American Feed Control Officials. Oxford: AAFCO, 2008. 
AZARKAN, M.; EL MOUSSAOUI, A.; VAN WUYTSWINKEL, D.; DEHON, G.; LOOZE, Y. Fractionation and purification of the enzymes stored in the latex of Carica papaya. Journal of Chromatography B: Analytical Technologies in the Biomedical and Life Sciences, v. 790, n. 1-2, p. 229-238, 2003. doi: 10.1016/ S1570-0232(03)00084-9.

BARBOSA,N.A.A.;SAKOMURA,N.K.;FERNANDES,J.B. K.; DOURADO, L. R. B. Enzimas exógenas no desempenho e na digestibilidade ileal de nutrientes em frangos de corte. Pesquisa Agropecuária Brasileira, v. 43, n. 6, p. 755-762, 2008. doi: 10.1590/S0100-204X2008000600012.

BATISTUZZO, J. A. O.; ETO, Y.; ITAYA, M. Formulário médico-farmacêutico. 3. ed. São Paulo: Tecnopress, 2006.

CARCIOFI, A. C. Uma visão industrial: curso teórico e prático em nutrição de cães e gatos. Jaboticabal: Unesp, 2008. (Curso).

CARCIOFI, A. C.; TAKAKURA, F. S.; OLIVEIRA, L. D.; TESHIMA, E.; JEREMIAS, J. T.; BRUNETTO, M. A.; PRADA, F. Effects of six carbohydrate sources on dog diet digestibility and post-prandial glucose and insulin response. Journal of Animal Physiology and Animal Nutrition, v. 92, n. 3, p. 326-336, 2008. doi: 10.1111/j.14390396.2007.00794.x.

CASE, L.P.;DARISTOTLE, L.; HAYEK, M. G.; RAASCH,M. F. Digestion and absorption. In: CASE, L. P.; DARISTOTLE, L.; HAYEK, M. G.; RAASCH, M. F. Canine and feline nutrition: a resource for companion animal professional. 3. ed. Maryland Heights, MO: Mosby, 2011. p. 45-53.

CAVALARI, A. P. M.; DONZELE, J. L.; VIANA, J. A.; ABREU, M. L. T.; OLIVEIRA, A. L. S.; FREITAS, L. S.; PEREIRA, A. A.; CARCIOFI, A. C. Determinação do valor nutritivo de alimentos energéticos e protéicos utilizados em rações para cães adultos. Revista Brasileira de Zootecnia, v. 35, n. 5, p. 1985-1991, 2006. doi: 10.1590/ S1516-35982006000700015.

CECCHI, H. M. Fibra bruta (conceito antigo) - fibra dietética (conceito novo). In: CECCHI, H. M. Fundamentos teóricos e práticos em análise de alimentos. 2. ed. Campinas: Unicamp, 2003. p. 79-83.
COWIESON, A. J.; ACAMOVIC, T.; BEDFORD, M. R. Using the precision-feeding bioassay to determine the efficacy of exogenous enzymes: a new perspective. Animal Feed Science and Technology, v. 129, n. 1-2, p. 149-158, 2006. doi: 10.1016/j.anifeedsci.2005.12.008.

DE PILLI, T.; LEGRAND, J.; GIULIANI, R.; DEROSSI, A.; SEVERINI, C. Effect of processing variables and enzymatic activity on wheat flour dough extruded under different operating conditions. Food Technology and Biotechnology, v. 47, n. 4, p. 404-412, 2009.

FARCAS, A. K.; LARSEN, J. A.; FASCETTI, A. J. Evaluation of fiber concentration in dry and canned commercial diets formulated for adult maintenance or all life stages of dogs by use of crude fiber and total dietary fiber methods. Journal of the American Veterinary Medical Association, v. 242, n. 7, p. 936-940, 2013. doi: 10.2460/ javma.242.7.936.

FÉlIX, A. P.; CARVAlHO, M. P.; AlARÇA, L. G.; BRITO, C. B. M.; OLIVEIRA, S. G.; MAIORKA, A. Effects of the inclusion of carbohydrases and different soybean meals in the diet on palatability, digestibility and fecal characteristics in dogs. Animal Feed Science and Technology, v. 174, n. 3-4, p. 182-189, 2012. doi: 10.1016/j. anifeedsci.2012.03.013.

FUENTE, J. M.; SOTO-SALANOVA, M. Utilización de enzimas para mejorar el valor nutritivo de las dietas maízsorgo/soja en avicultura. Selecciones Avícolas, v. 39, n. 5, p. 271-275, 1997.

GARCIA, E. R. M.; MURAKAMI, A. E.; BRANCO, A. F.; FURLAN, A. C.; MOREIRA, I. Efeito da suplementação enzimática em rações com farelo de soja e soja integral extrusada sobre a digestibilidade de nutrientes, o fluxo de nutrientes na digesta ileal e o desempenho de frangos. Revista Brasileira de Zootecnia, v. 29, n. 5, p. 1414-1426, 2000. doi: 10.1590/S1516-35982000000500020.

GRZONKA, Z.; JANKOWSKA, E.; KASPRZYKOWSKI, F.; KASPRZYKOWSKA, R.; LANKIEWICZ, L.; WICZK, W.; WIECZERZAK, E.; CIARKOWSKI, J.; DRABIK, P.; JANOWSKI, R.; KOZAK, M.; JASKÓLSKI, M.; GRUBB, A. Structural studies of cysteine proteases and their inhibitors. Acta Biochimica Polonica, v. 48, n. 1, p. 1-20, 2001. 
KUMAR, C. G.; TAKAGI, H. Microbial alkaline proteases: from a bioindustrial viewpoint. Biotechnology Advances, v. 17, n. 7, p. 561-594, 1999.

LOGATO, P. V. R. Nutrição e alimentação de peixes de água doce. Viçosa: Aprenda Fácil, 2000.

MEZHLUMYAN, L. G.; KASYMOVA, T. D.; YULDASHEV, P. K. Proteinases from Carica papaya latex. Chemistry of Natural Compounds, v. 39, n. 3, p. 223-228, 2003. doi: 10.1023/A:1025466030937.

MITCHEL, R. E. J.; CHAIKEN, I. M.; SMITH E. L. The complete amino acid sequence of papain. The Journal of Biological Chemistry, v. 245, n. 14, p. 3485-3492, 1970.

MOUTIM, V.; SILVA, L. G.; LOPES, M. T. P.; FERNANDES, G. W.; SALAS, C. E. Spontaneous processing of peptides during coagulation of latex from Carica papaya. Plant Science, v. 142, n. 2, p. 115-121, 1999. doi: 10.1016/S01689452(98)00226-X.

MOXHAM, G. The Waltham feces scoring system: a tool for veterinarians and pet owners: how does your pet rate? Waltham Focus, v. 11, n. 2, p. 24-25, 2001.

MURRAY, S. M.; PATIL, A. R.; FAHEY JUNIOR, G. C.; MERCHEN, N. R.; HUGHES, D. M. Raw and rendered animal by-products as ingredients in dog diets. Journal of Animal Science, v. 75, n. 9, p. 2497-2505, 1997. doi: 10.2527/1997.7592497x.

NATIONAL RESEARCH COUNCIL (NRC). Ad hoc committee on dog and cat nutrition. Nutrient requirements of dogs and cats. Washington, DC: National Academies, 2006.

OLIVEIRA, A. L. Maciez da carne bovina. Cadernos Técnicos de Veterinária e Zootecnia, n. 33, p. 7-18, 2000.

OLIVEIRA, L. D.; TAKAKURA, F. S.; KIENZLE, E.; BRUNETTO, M. A.; TESHIMA, E.; PEREIRA, G. T.; VASCONCELLOS, R. S.; CARCIOFI, A. C. Fibre analysis and fibre digestibility in pet foods: a comparison of total dietary fibre, neutral and acid detergent fibre and crude fibre. Journal of Animal Physiology and Animal Nutrition, v. 96, n. 5, p. 895-906, 2012. doi: 10.1111/j.1439-0396.2011.01203.x.
POND, W. G.; CHURCH, D. C.; POND, K. R. Measurement of feed and nutrient utilization. In: POND, W. G.; CHURCH, D. C.; POND, K. R. Basic animal nutrition and feeding. 4. ed. Hoboken: John Wiley \& Sons, 1995. p. 112-138.

RUIZ, U. S.; THOMAZ, M. C.; HANNAS, M. I.; FRAGA, A. L.; WATANABE, P. H.; SILVA, S. Z. Complexo enzimático para suínos: digestão, metabolismo, desempenho e impacto ambiental. Revista Brasileira de Zootecnia, v. 37, n. 3, p. $458-468,2008$. doi: $10.1590 /$ S1516-35982008000300011.

SÁ, F. C.; VASCONCELLOS, R. S.; BRUNETTO, M. A.; FILHO, F. O. R.; GOMES, M. O. S.; CARCIOFI, A. C. Enzyme use in kibble diets formulated with wheat bran for dogs: effects on processing and digestibility. Journal of Animal Physiology and Animal Nutrition, v. 97, p. 51-59, 2013. Supplement 1. doi: 10.1111/jpn.12047.

SHIN, H. H.; PARK, B. S.; LEE, S. H.; KIM, Y. S.; HWANG, J. K. Effects of extrusion and enzyme treatment on characteristics of whole grains. Journal of Food Science and Technology, v. 37, n. 1, p. 15-22, 2005.

SILVA, L. G.; GARCIA, O.; LOPES, M. T. P.; SALAS, C. E. Changes in protein profile during coagulation of latex from Carica papaya. Brazilian Journal of Medical and Biological Research, v. 30, n. 5, p. 615-616, 1997. doi: 10.1590/S0100-879X1997000500007.

TORTOLA, L.; SOUZA, N. G.; ZAINE, L.; GOMES, M. O. S.; MATHEUS, L. F. O.; VASCONCELLOS, R. S.; CARCIOFI, A. C. Enzyme effects on extruded diets for dogs with soybean meal as a substitute for poultry by product meal. Journal of Animal Physiology and Animal Nutrition, v. 97, p. 39-50, 2013. Supplement 1. doi: 10.1111/jpn.12009.

TWOMEY, L. N.; PLUSKE, J. R.; ROWE, J. B.; CHOCT, M.; BROWN, W.; MCCONNELL, M. F.; PETHICK, D. W. The effects of increasing levels of soluble non-starch polysaccharides and inclusion of feed enzymes in dog diets on fecal quality and digestibility. Animal Feed Science and Technology, v. 108, n. 1-4, p. 71-82, 2003a. doi: 10.1016/S0377-8401(03)00161-5.

TWOMEY, L. N.; PLUSKE, J. R.; ROWE, J. B.; CHOCT, M.; BROWN, W.; PETHICK, D. W. The replacement value 
of sorghum and maize with or without supplemental enzymes for rice in extruded dog foods. Animal Feed Science and Technology, v. 108, n. 1-4, p. 61-69, 2003 b. doi: 10.1016/S0377-8401(03)00168-8.

WANG, J. J.; GARLICH, J. D.; SHIH, J. C. H. Beneficial effects of versazyme, a keratinase feed additive, on body weight, feed conversion, and breast yield of broiler chickens. The Journal of Applied Poultry Research, v. 15, p. 544-550, 2006. doi: 10.1093/japr/15.4.544.

ZANELLA, I.; SAKOMURA, N. K.; SILVERSIDES, F. G.; FIGUEIREDO, A.; PACK, M. Effect of enzyme supplementation of broiler diets based on corn and soybeans. Poultry Science, v. 78, n. 4, p. 561-568, 1999. doi: $10.1093 / \mathrm{ps} / 78.4 .561$. 